\title{
Von Hippel-Lindau Peptide Vaccine
}

National Cancer Institute

\section{Source}

National Cancer Institute. Von Hippel-Lindau Peptide Vaccine. NCI Thesaurus. Code C2492.

A cancer vaccine composed of peptides derived from a tumor-associated protein encoded by a mutated Von Hippel-Lindau (VHL) oncogene. VHL peptide vaccine may stimulate a cytotoxic $\mathrm{T}$ cell response ag ainst tumor cells expressing the VHL tumorassociated protein. $(\mathrm{NCl04})$ 